\title{
Groundwater Resource Mapping through the Integration of Geology, Remote Sensing, Geographical Information Systems and Borehole Data in Arid-Subarid Lands at Turkana South Sub-County, Kenya
}

\author{
Daniel Nyaberi, Justus Barongo, Patrick Kariuki, George Ogendi, Evans Basweti
}

Kisii University, Kisii, Kenya

Email: nyaberimogaka@gmail.com

How to cite this paper: Nyaberi, D., Barongo, J., Kariuki, P., Ogendi, G., \& Basweti, E. (2019). Groundwater Resource Mapping through the Integration of Geology, Remote Sensing, Geographical Information Systems and Borehole Data in Arid-Subarid Lands at Turkana South Sub-County, Kenya. Journal of Geoscience and Environment Protection, 7, 53-72.

https://doi.org/10.4236/gep.2019.712004

Received: October 21, 2019

Accepted: December 13, 2019

Published: December 16, 2019

Copyright $\odot 2019$ by author(s) and Scientific Research Publishing Inc. This work is licensed under the Creative Commons Attribution International License (CC BY 4.0).

http://creativecommons.org/licenses/by/4.0/

\begin{abstract}
The integrated approach of various techniques which historically have been used independently is key to successful exploration, development, exploitation and management of the groundwater resources. The integration of Remote Sensing (RS), Geographical Information Systems (GIS) and Borehole data has been used in the study area to assess their applicability in groundwater investigation. The area of study lies in the arid and semi-arid lands (ASALs) where principally remote sensing data has been used in extraction of various thematic maps (lithology, lineament, drainage density, and Digital Elevation Model Maps) for groundwater assessment. The GIS platform was used in integrating the RS data and data of productive boreholes. The lineaments generated through remote sensing agree well with structural geology of the area, where high density lineament points overlays the points of intense faulting. Lineaments found in the area correlate well with fault zones, fractures, and lithological contrasts as supported by geological map and structural map. Weathering, faulting and fracturing of the rocks mean a possible increase or a reduction in specific capacities as observed in productive boreholes in sedimentary rocks or igneous/basaltic rocks of the area. Similarly, it is noted that the degree of faulting affects the degree of radius of influence of a borehole in a particular area. These analyses show that groundwater potential within the Sub-County varies spatially with high dependency on geological structures in the basement region and more on geology within the volcanic and younger sediments.
\end{abstract}




\section{Keywords}

Arid-Subarid, Groundwater, GIS, Remote Sensing, Borehole Data, Integration

\section{Introduction}

Water availability in ASALs will greatly spur development in the world for it is an important factor for growth and development. There is affirmation there is shortage of water for drinking and agricultural usage and thus a vital subject to be addressed mostly in arid and semi-arid regions (Kamal \& Hamid, 2011). It is important to note that water unavailability in ASALs is not a factor of nonexistence of water but lack of commitment to search for the same resource in these areas. Notably according to Mortimore (2009), 35 percent of the world population is estimated to live in ASALs whose livelihoods remain normally safe when there is good rainfall, whereas whenever there is a prolonged dry spell, there is crop failure and minimal vegetation cover for livestock and wildlife, and in most instances contaminated supplies of drinking water. The water problem is like a contagious disease as according to World Economic Forum (2017), the scale and interconnectedness of the top global risks are increasingly tied to water and therefore water management locally poses global impacts, and worldwide developments have local impacts (Wada et al., 2016). In the ASALs surface water is scarce and so the savior is centred in groundwater investigation and exploitation.

Exploration of underground water in countries affected by water scarcity needs the application of effective ways geared towards saving the resources they mostly lack, time and money (Jawad \& Yahya, 2013). GIS allows for rapid and an easier way of accessing the large volumes of data and presents such powerful output abilities (summary statistics, graphs, and maps) that are custom-made toward meeting particular needs. Groundwater by description is subterranean and in hard rock it is stored within fractures and the weathered zones and the use of topographic data has proven useful to help identifying lineaments/fracture systems/deeper weathered zones in potential areas. The option of applying remote sensing data in outlining utmost favorable locations for underground water investigation has been examined by Jawad \& Yahya (2013) through the application of unsupervised classification to a Landsat ETM+ image. Jawad \& Yahya (2013) did successfully use the different GIS tasks in intersecting and spatial querying of data to yield a map indicating the most favorable spots for further underground water investigation.

Digital elevations models (DEMs) and geological maps have been applied in the GIS platform to successfully delineate areas with groundwater occurrences (Mogaji, Aboyeji, \& Omosuyi, 2011). Similarly, the identification of remote sensing based data used spatially on layers of groundwater governing parameters 
using GIS has been made possible for generation of the underground water potential zone maps (Anbazhagan \& Manivel, 2010). Fundamentally, Remote Sensing and GIS techniques are recommended in areas that have ground water exploration challenges especially on a regional scale and areas not very accessible (Obimba, Alaga, \& Alwadood, 2017). It is established by Anbazhagan \& Manivel (2010) that remote sensing methods with prominence on lineament identification play a vital application in underground water hunting in hard rock areas and thus confirmed designate as tremendously suitable application in the morphometric analysis and thus underground water studies.

Groundwater exploration in ASALs has historically been challenging when approached by single conventional methods. Huge successes have been reported in cases of integrated approach especially where remote sensing is principally applied to zero down to targets where geophysical methods are used for ground truthing. The achieved results in this research will help to reveal the lithology and structures beneath the Turkana South Sub-County and their relation to groundwater occurrence, and therefore help to develop maps indicating suitable groundwater prospective zones. These results will guide on the best points to drill to avoid the problem of siting uneconomical boreholes.

Turkana South Sub-County lies in southern part of Turkana County which is the largest of all the forty-seven (47) counties in the Kenya. The Sub-County's coverage in area is $18,000 \mathrm{~km}^{2}$ and lies between Longitudes $35^{\circ} 10^{\prime}$ and $36^{\circ} 45^{\prime}$ East and between Latitudes $1^{\circ} 0^{\prime}$ and $3^{\circ} 0^{\prime}$ North. The Sub-County (Figure 1 ), is bordered by the country of Uganda in the west, Lake Turkana to the east, West Pokot County in the southern, Baringo County to the south eastern and Samburu County to the south-south east. The main drainage is controlled by Kerio and the Suguta rivers with their tributaries (e.g. Kalabata, Kasamanang and Nasaken). According to Sultan (1970), these sandy rivers carry water only immediately after heavy rainfall, although they contain water at depth and these supplies are of considerable importance in this arid region.

Turkana South is a semi-arid land area with rainfall of only about an average of $250 \mathrm{~mm}$ per annum (Sultan, 1970), and is symbolized by warm and hot climate. This is a reflection of the Turkana county climate whose temperatures varies in the range of $20^{\circ} \mathrm{C}$ to $41^{\circ} \mathrm{C}$ and at a mean of $30.5^{\circ} \mathrm{C}$ (Government of Kenya, 2013) with varied seasons of rainfall during the long rains (akiporo) from the months of April to July and the short rains covering the months of October to November, ranging $52 \mathrm{~mm}$ to $480 \mathrm{~mm}$ annually (Turkana County Government Report, 2015).

The Geology of south Turkana area has been analyzed by Dodson (1963) with an extensive description of the Miocene basalts. Champion (1935a) in accounting for the occurrence of nephelinites in the region has further given an explanation of the physiography and volcanic geology of the regions, south and west of Lake Rudolf. The geology of Turkana South Sub-County is represented by Basement system, Tertiary volcanic rocks, and Quaternary sediments (Figure 2). 


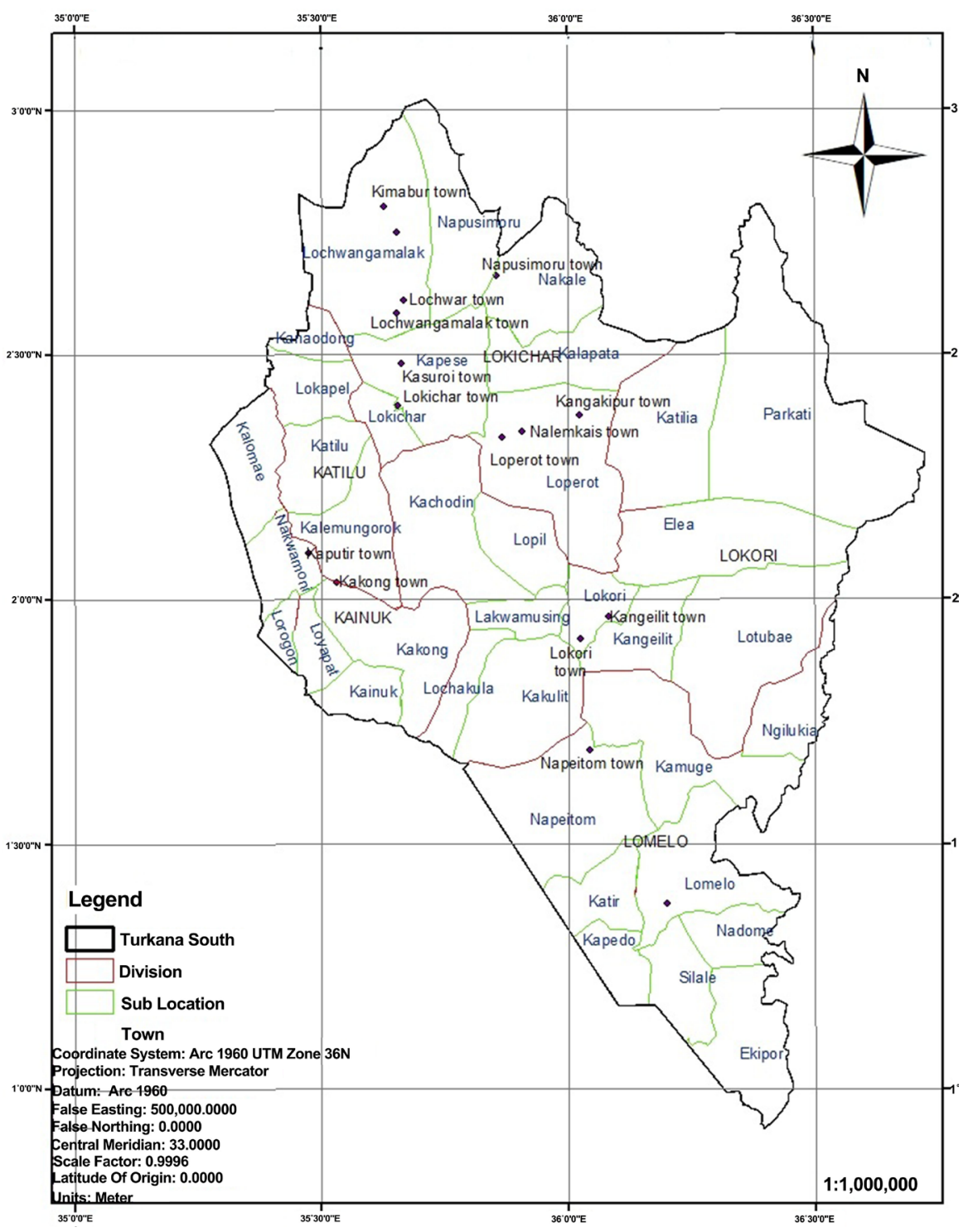

Figure 1. Location of turkana south sub-county within turkana county in Kenya.

The basement comprise principally of gneisses, schists and marbles derived from various types of sandstone rocks, sediments-grits, limestone formations and shales whose metamorphosis has been achieved by heat and pressure or by impregnation by pervading fluids.

The Tertiary volcanic rocks have an origin believed to have emanated from a number of central volcanoes consisting of the augite and analcime basalts, phonolites, nephelinites, olivine basalts and rhyolites (Sultan, 1970). The augite and analcime basalts overlie the Turkana Grits, and these formations are the oldest volcanic rocks which are generally fine-grained basalts. Examination of the outcrops presents groundmass mainly of the analcime while augite occurs as phenocrysts within the groundmass in forms of enstatite-augite, andesine-labradorite and magnetite, with a small amount of interstitial analcime. Some pockets appearing centrally in the project region are made of phonolites and nephelinites. 


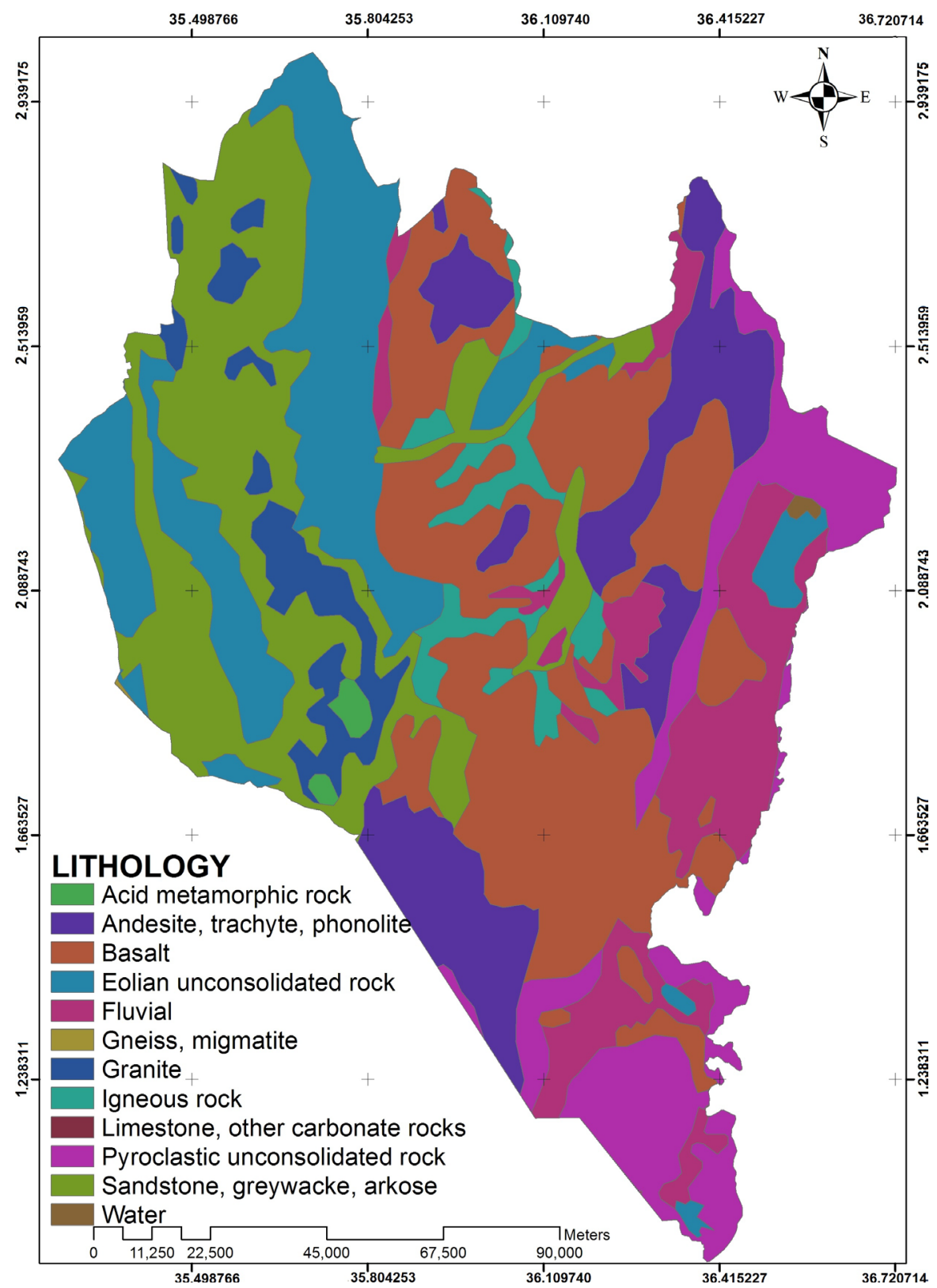

Figure 2. Geological map of Turkana South Sub-County showing borehole locations.

Medium grey in colour with microphenocrysts of nepheline, the phonolite rock is partly altered to sodalite, and turbid anorthoclase felspar set in a fine-grained groundmass of green aegirine-augite, anorthoclase and nepheline. Towards the end of the extrusion was the evolution of basic phase resulting into deposition of the olivine basalts which are the older basalt series in the area. The prominence of protective caps on hills which have withstood the erosional conditions are mainly mafic lavas of basalt and pyroclastics rhyolites. The lacustrine deposits date from the Pleistocene and continuing into the recent period, forms the Quaternary sediments which includes the lake beds which are made up of sandy soils derived from basement system rocks, and occasionally light red, fine-textured 
and powdery sandy soils derived mainly from lavas.

The hydrogeology of Turkana South Sub-County is interesting for its geological setting encompasses; the metamorphic rocks, igneous rocks, and sedimentary rocks. Equally, recent sedimentation associated with river channels have been associated with groundwater extraction where shallow wells are drilled on or proximate to the river channels (Gwynne, 1969). The nature of groundwater occurrence in the area is expected to range from high to moderate to low and even poor potential which is necessitated by the geology (metamorphic, igneous and sedimentary rocks).

Predominantly, basement gneisses presents poor aquifers, however, fracture and fault zones offer the best areas for groundwater movement, recharge and storage. Evidently, a case is presented and attested from confirmation change in the course of the river in line with the fault-zone of faulting near the Kerio River east of Chepkum (Mason \& Gibson, 1957). Further indication of existence and location of faults observed in the area as supported by the connotation of sheared and brecciated rocks coupled with secondary chalcedonic quartz of hydrothermal origin (Mason \& Gibson, 1957). Equally, according to McCall (1964), confirmatory mark of faulted zones is evidence with the existence of amphibolite bands in the gneisses and schists.

Thus the degree of weathering or fracturing affecting the rock formations in the area is a guiding factor to whether the material serves as a good aquifer. This is rampant as indeed noted by Fairburn \& Matheson (1970) where there is dominance of Trellis drainage, a feature of faulting than dendritic drainage. Highly permeable aquifers in the area are a product of volcanic rocks, the orientation of the basalt flow exceedingly show such physical appearance. Large quantities of water are produced by wells drilled on strata proximate streams essentially formed of unconsolidated rocks chiefly of gravels and sands. There is high correlation between drainage system and groundwater occurrence in the study area, where in the basement areas there is increased potential with increasing drainage density. Thus the structures supporting drainage impact on pints of water impoundment or defines areas where the water recharge happens as evidenced by the distribution of the boreholes in the area of study in relation to the drainage system (Figure 3).

\section{Materials and Methods}

\subsection{Research Approach}

The research employed three approaches in groundwater resource mapping of the study area. The first approach used remote sensing where sentinel 1 remote sensing data was used to determine single polarization ( $\mathrm{HH}$ or VV) and equally the double polarization $(\mathrm{HH}+\mathrm{HV}$ or $\mathrm{VV}+\mathrm{VH})$. This is normally realized by one transmit chain (switchable to $\mathrm{H}$ or $\mathrm{V}$ ) and two parallel receiver chains for $\mathrm{H}$ and $\mathrm{V}$ polarization and on synthesis generated lineaments which were key in analysis of the terrain. The second was the use of GIS to overlay structural 


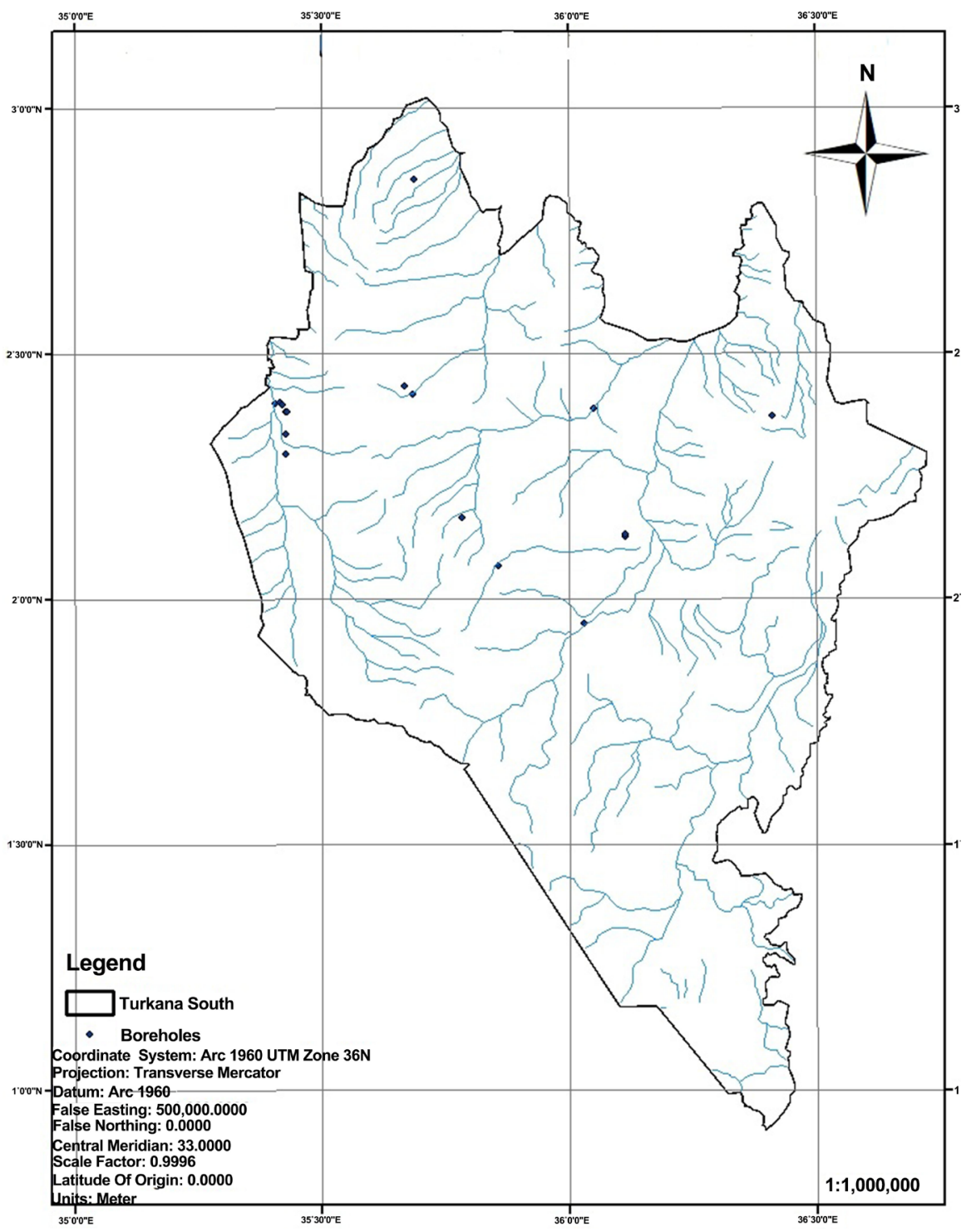

Figure 3. Boreholes overlaid on drainage Map of the area under study.

geology and thus the correlation between lineaments and geological structures synthesized. Lastly the application of borehole data from the area which shows correlation of geological structural controls to groundwater mining.

There was an assembly in hardcopy of maps of the geology, the topography, and structural geology at a scale of 1:50,000. The maps were scanned, uploaded to the GIS platform, georeferenced and digitized on the aspect required. Subsequently, satellite images of sentinel 1 remote sensing data covering the study area were downloaded. In this research the data from the primary conflict-free modes over land, IW was used.

\subsubsection{Application of Remote Sensing}

Using multispectral data from the European Space Agency satellite Sentinel-1A, false-colour composite image for the study area by combination of selected spectral band ratios was used to develop maps of Sentinel 1a cross-polarized 
(VH) image and Sentinel 1a VV Polarized image. The decision to use VH, is that they demonstrate a good difference and sufficient detail to license the mapping of hydrographic network where minimum vegetation is available (Saint-Jean \& Singhroy, 2000), whereas the VV polarization permits a better positioning of alignments in form of faults, scarps, banks and therefore vital in mapping roughness variations. The sentinel series observes the earth at high resolution and therefore is very useful in groundwater management and other applications and information services.

\subsubsection{Application of GIS}

Maps were generated using GIS by overlaying different outputs including layers of lineaments generated from RS data, geological structures, lithological formations and drainage network with all attributes associated with each layer. Subsequently borehole data were overlaid to maps to correlate the positions to drainage and geological structures.

\subsubsection{Application of Borehole Data}

Historically fracture identification, now lineaments from digital elevation models (DEM) is the most common use of satellite data for borehole siting. Indeed successfully (Per Sander, Chesley, \& Minor, 1996) used Landsat TM imagery whose analysis extracted lineaments which greatly used to a greater success in siting of boreholes. The existing wells in the area were cascaded using geographic information system tools and remote sensing information to indicate how they relate with both lineament and geological structures. Borehole data from the records were used (Table 1 ) including water strike levels, water rest levels and yields whose locations have spatially been subsequently correlated with the lineaments (Figure 4) and structural geology (Figure 5) of the area.

The borehole data was analyzed to give the applied specific capacities of wells in the area and a correlation was done to assess the differences noted in the wells found in high density lineament areas and the low density lineament areas. Specific capacity calculations were done based on the drawdown achieved at the end of a 24 hour pumping period. The borehole production tests of existing boreholes in the study area were considered for the determination of specific capacities. Accordingly, the calculations followed Equation (1), as developed by Lohman et al. (1972), where specific capacity of a well is the pumping rate divided by drawdown (Equation (2)), given by:

$$
S C=\frac{Q}{S}
$$

where;

$S C$ : is specific capacity, in cubic metre per hr. per metre;

$Q$ : is the pumping rate, in cubic metres per hr.; and

$s$ : is drawdown in the pumped well, in metres and

$$
s=d-d 0
$$


Table 1. Information of boreholes used in the study.

\begin{tabular}{cccccccc}
\hline S/No & ID & Longitude & Latitude & $\begin{array}{c}\text { Total depth } \\
(\mathrm{m})\end{array}$ & $\begin{array}{c}\text { M_WSL } \\
(\mathrm{m})\end{array}$ & $\begin{array}{c}\text { WRL } \\
(\mathrm{m})\end{array}$ & $\begin{array}{c}\text { Yield } \\
\left(\mathrm{m}^{3} / \mathrm{hr} .\right)\end{array}$ \\
\hline 1 & C 5615 & 35.500000 & 1.766700 & 100 & 80 & 16 & 0.96 \\
2 & C 5859 & 35.500000 & 1.500000 & 55 & 49 & 39 & 6 \\
3 & C 5616 & 35.533300 & 1.800000 & 70 & 55 & 43 & 0.84 \\
4 & C 6547 & 36.083300 & 1.333300 & 20 & 17 & 13.9 & 10.2 \\
5 & C 5836 & 35.658300 & 2.362500 & 80 & 10 & 7 & 0.24 \\
6 & C 3789 & 35.666700 & 2.383300 & 43 & 15 & 11 & 4.56 \\
7 & C 5872 & 36.044400 & 1.954200 & 35 & 23 & 30 & 12 \\
8 & C 5871 & 35.933300 & 2.000000 & 25 & 14 & 7 & 7.2 \\
9 & C 9769 & 35.833300 & 2.419400 & 24.9 & 12 & 3.9 & 0.7 \\
10 & C 9768 & 35.800000 & 2.418900 & 141.7 & 117 & 24.1 & 0.15 \\
11 & C5610 & 35.413415 & 2.391318 & 52.5 & 46 & 9.3 & 1.920 \\
12 & C6554 & 35.929274 & 2.001337 & 40 & 24 & 14.34 & 0.960 \\
13 & C5855 & 35.928565 & 2.105245 & 70 & 50 & 12.3 & 1.200 \\
14 & A & 35.650440 & 2.320944 & 100 & 52 & 13.4 & 7 \\
15 & B & 35.661060 & 2.343611 & 65 & 50 & 28 & 7 \\
\hline & & & & & & & \\
\hline
\end{tabular}

$d$ is the depth to water in the well, in feet; and

$d_{0}$ is the static depth to water when pumping begins, in metres

The data in Table 2 shows the specific capacity of particular boreholes. Transmissivity can be determined using different approaches; where if there is data of pumping rate, and draw down has been achieved across one log cycle then the Jacob's equation for determination of transmissivity is given as (Equation (3)).

$$
T=\frac{2.3 Q}{4 \pi \Delta s}
$$

where $T$ is transmissivity, $Q$ is the pumping rate, $\Delta s$ is the drawdown across one $\log$ cycle. In this research the drawdown from pumped boreholes was not recorded across one log cycle. Hence estimation of transmissivity has been done by Logan's method due the reason that only the value of specific capacities of boreholes were able to be calculated and thus used to estimate transmissivity using Equation (4) by Logan (1964):

$$
T=1.22 S c
$$

where $T$ is the transmissivity, and $\mathrm{Sc}$ is the specific capacity.

\section{Results}

\subsection{Lithology and Geological Structures}

The data used were the map of the geology of the region digitized, then curved 


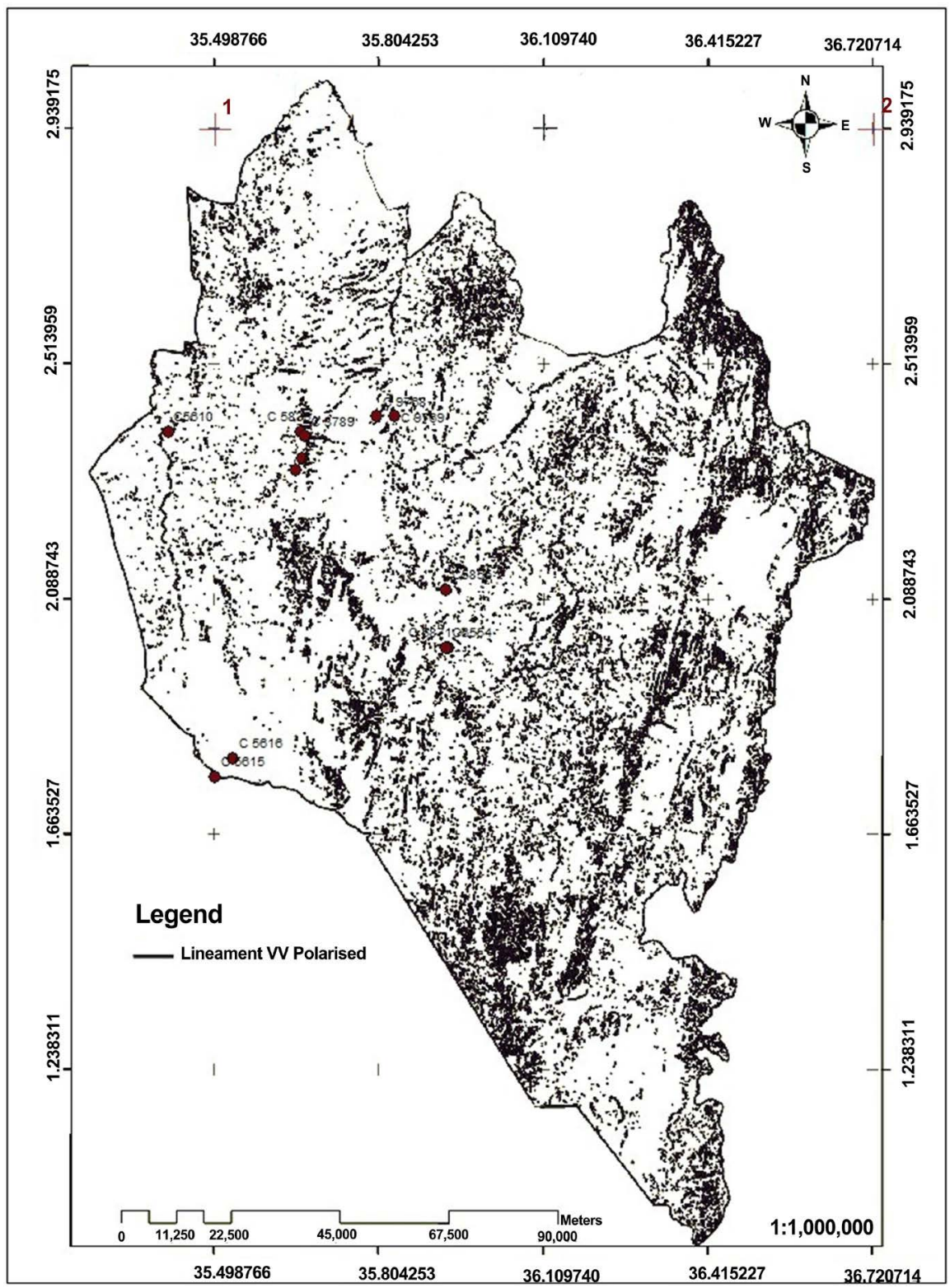

Figure 4. Correlation between borehole locations and lineament density.

out of combination of several geological maps of areas: Northern Turkana, Loiya, Lorugumu, Lodwar, Loiyangani, Karasuk, Loperot, Sekker, Kalossia and Maralal to produce resulting geological map of the study area (Figure 2). Equally the geological structures of the area were overlaid on the geological map (Figure 6) that also helped in determination of the correlation of the two in relation to groundwater potential of the area.

\subsection{Lineament Extraction}

In the study, the extraction of lineaments was achieved automatically by considering two central calculations: primary was the application of a filter in detection of the edges (contours). This was instrumental in establishing parts of 


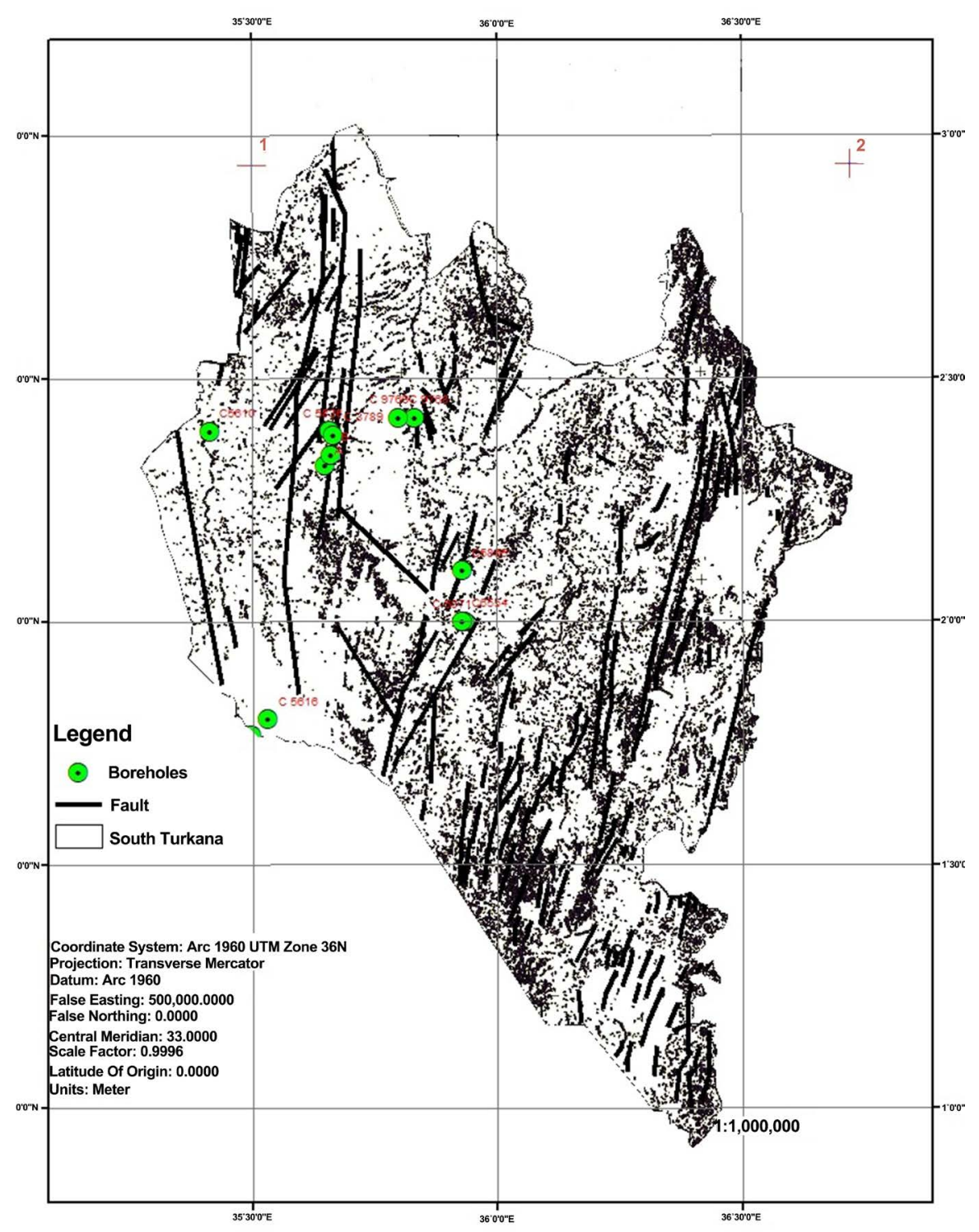

Figure 5. Boreholes overlaid on structural geology superimposed on lineament density map of study area.

sudden deviations for the numbers of neighboring pixels, which in this analysis are lineaments. The second step was the detection of lines. The mapping of lineament was made possible by the establishment of the geomorphological features like drainage channels, valleys, ridges, displacements, scarp faces and ridge passages, and aligned surface depressions. Thus in consideration of the data obtained from Sentinel 1A and further analysis, a lineament map was produced (Figure 7).

\subsection{Specific Capacities and Transmissivity of Boreholes in the Area}

The calculated specific capacities and estimated transmissivities are presented in Table 2. 
Table 2. Specific Capacities and Transmissivities of boreholes in the area.

\begin{tabular}{|c|c|c|c|c|c|c|c|}
\hline ID & $\begin{array}{l}\text { T-Depth } \\
\text { (m) }\end{array}$ & $\underset{(\mathrm{m})}{\text { M_WSL }}$ & $\begin{array}{l}\text { WRL } \\
\text { (m) }\end{array}$ & $\begin{array}{l}\text { Yield (Q) } \\
\text { in } \mathrm{m}^{3} / \text { day }\end{array}$ & $\begin{array}{c}\text { Draw } \\
\text { Down (s) } \\
\text { in } \mathrm{m}\end{array}$ & $\begin{array}{c}\text { Specific } \\
\text { Capacities (S) } \\
\text { in } \mathrm{m}^{2} / \text { day }\end{array}$ & $\begin{array}{l}\text { Transmissivities } \\
(\mathrm{T}) \text { in } \mathrm{m}^{2} / \text { day }\end{array}$ \\
\hline C 5615 & 100 & 80 & 16 & 23.04 & 44 & 0.523636364 & 0.638836 \\
\hline C 5859 & 55 & 49 & 39 & 144 & 13 & 11.07692308 & 13.51385 \\
\hline C 5616 & 70 & 55 & 43 & 20.16 & 16 & 1.26 & 1.5372 \\
\hline C 6547 & 20 & 17 & 13.9 & 244.8 & 15 & 16.32 & 19.9104 \\
\hline C 5836 & 80 & 10 & 7 & 5.76 & 20.4 & 0.282352941 & 0.344471 \\
\hline C 3789 & 43 & 15 & 11 & 109.44 & 18 & 6.08 & 7.4176 \\
\hline C 5872 & 35 & 23 & 30 & 288 & 20 & 14.4 & 17.568 \\
\hline C 5871 & 25 & 14 & 7 & 172.8 & 18.6 & 9.290322581 & 11.33419 \\
\hline C 9769 & 24.9 & 15 & 3.9 & 16.8 & 74.1 & 0.226720648 & 0.276599 \\
\hline C 9768 & 141.7 & 117 & 24.1 & 3.6 & 10 & 0.36 & 0.4392 \\
\hline C5610 & 52.5 & 46 & 9.3 & 46.080 & 14.5 & 3.177931034 & 3.877076 \\
\hline C6554 & 40 & 24 & 14.34 & 23.040 & 4 & 5.76 & 7.0272 \\
\hline C5855 & 70 & 50 & 12.3 & 28.800 & 14.5 & 1.986206897 & 2.423172 \\
\hline A & 100 & 52 & 13.4 & 168 & 42.32 & 3.969754253 & 4.8431 \\
\hline B & 65 & 50 & 28 & 168 & 17.5 & 9.6 & 11.712 \\
\hline
\end{tabular}

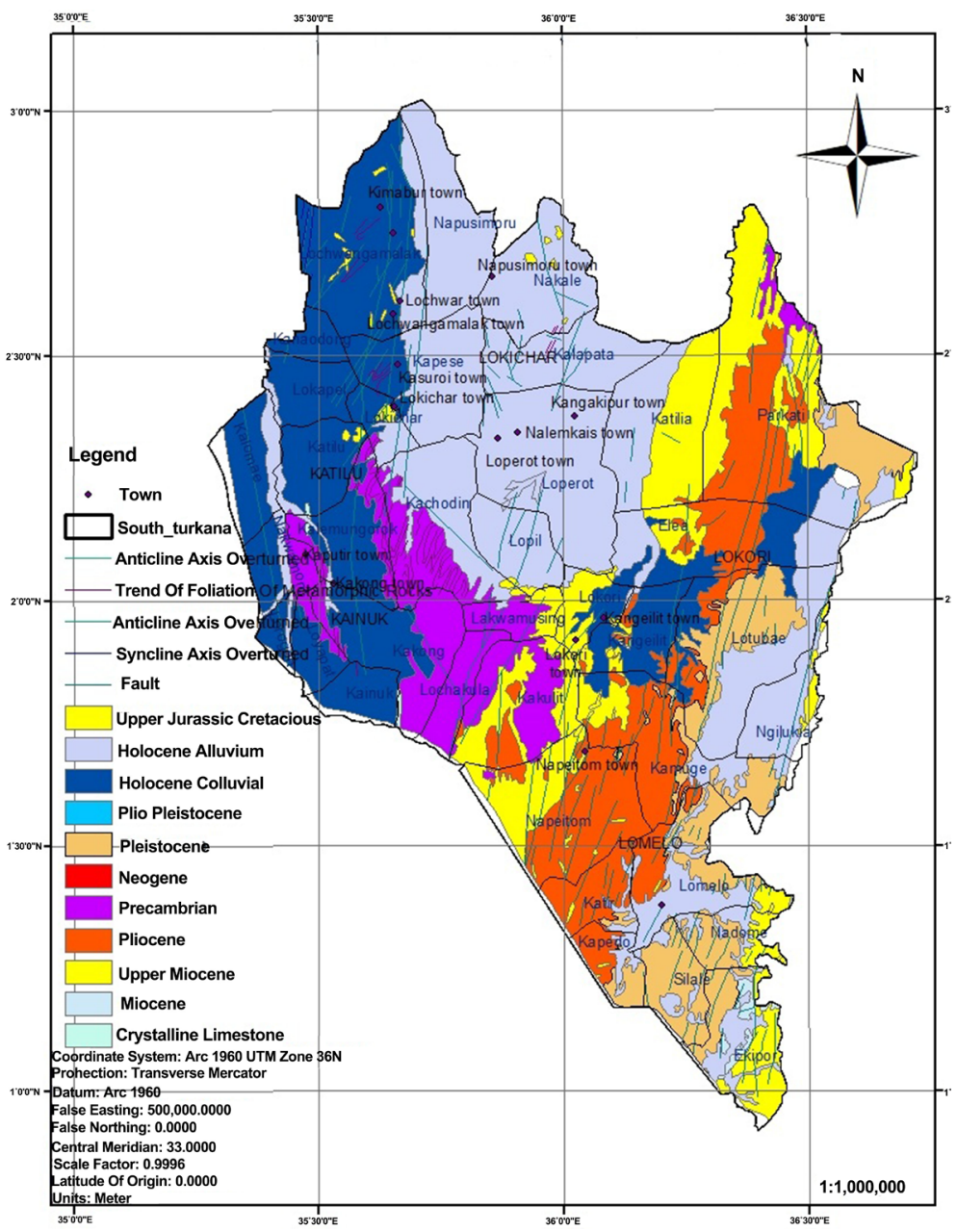

Figure 6. Geological structures overlaid on the geological map. 


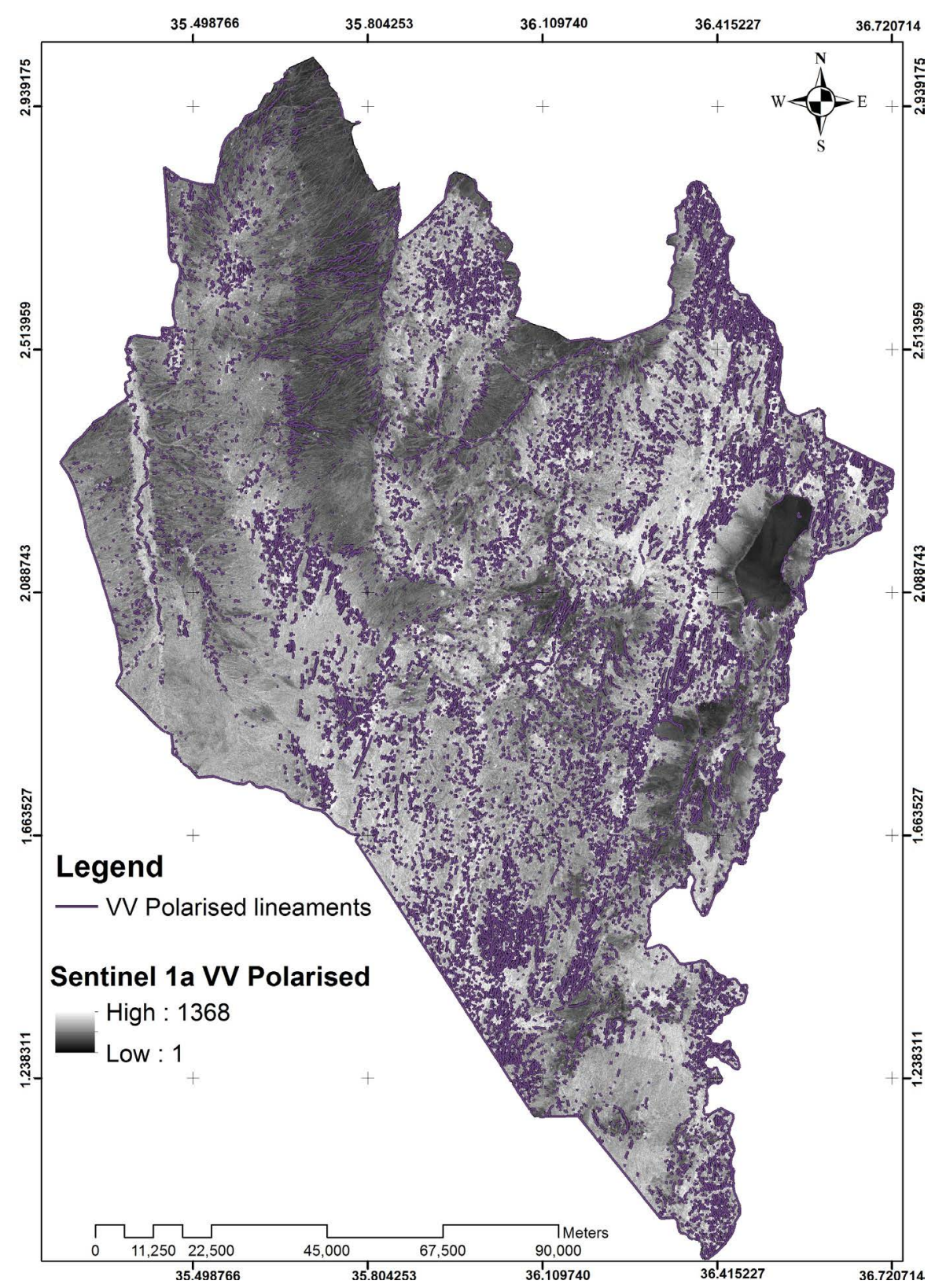

Figure 7. Map of the study area showing Sentinel 1a VV Polarized with lineament VV polarized (pink lines).

Klimentov \& Pykhachev (1961) by using data of drawdown from wells in a confined aquifer were able to establish that there exists a relationship between radius $\left(r_{2}\right)$ of influence, drawdown $(\mathrm{s})$ and well transmissivity $(\mathrm{T})$ given as (Equation (5)):

$$
r 2=2 s \sqrt{ } T
$$

This implies a direct relationship between the radius of influence to that for drawdown and of the transmissivity of the aquifer. Tentatively by using equation 5 , radii of influence were determined for various wells in the study area (Table 3). 
Table 3. Specific capacities, transmissivities and radius of influence in different boreholes.

\begin{tabular}{|c|c|c|c|c|c|c|c|}
\hline ID & $\begin{array}{c}\text { Yield (Q) in } \\
\mathrm{m}^{3} / \text { day }\end{array}$ & $\begin{array}{c}\text { Draw Down } \\
\left(s^{\prime}\right) \text { in } \mathrm{m}\end{array}$ & $\begin{array}{l}\text { Specific Capacities } \\
(\mathrm{S}) \text { in } \mathrm{m}^{2} / \text { day }\end{array}$ & $\begin{array}{c}\text { Transmissivities ( } \mathrm{T} \text { ) } \\
\text { in } \mathrm{m}^{2} / \text { day }\end{array}$ & $\begin{array}{l}2 \text { (Draw Down } \\
(\mathrm{s}) \text { in } \mathrm{m}\end{array}$ & $\begin{array}{l}\text { Square root of } \\
\text { Transmissivity }\end{array}$ & $\begin{array}{l}\text { Radius of influence } \\
\text { (r2) in } \mathrm{m}\end{array}$ \\
\hline C 5615 & 23.04 & 44 & 0.523636364 & 0.638836 & 88 & 0.799272396 & 70.33597088 \\
\hline C 5859 & 144 & 13 & 11.07692308 & 13.51385 & 26 & 3.676118354 & 95.57907721 \\
\hline C 5616 & 20.16 & 16 & 1.26 & 1.5372 & 32 & 1.239838699 & 39.67483837 \\
\hline C 6547 & 244.8 & 15 & 16.32 & 19.9104 & 30 & 4.462107126 & 133.8632138 \\
\hline C 5836 & 5.76 & 20.4 & 0.282352941 & 0.344471 & 40.8 & 0.586916168 & 23.94617965 \\
\hline C 3789 & 109.44 & 18 & 6.08 & 7.4176 & 36 & 2.723527125 & 98.0469765 \\
\hline C 5872 & 288 & 20 & 14.4 & 17.568 & 40 & 4.191419807 & 167.6567923 \\
\hline C 5871 & 172.8 & 18.6 & 9.290322581 & 11.33419 & 37.2 & 3.366629405 & 125.2386139 \\
\hline C 9769 & 16.8 & 74.1 & 0.226720648 & 0.276599 & 148.2 & 0.525926982 & 77.94237872 \\
\hline C 9768 & 3.6 & 10 & 0.36 & 0.4392 & 20 & 0.662721661 & 13.25443322 \\
\hline C5610 & 46.080 & 14.5 & 3.177931034 & 3.877076 & 29 & 1.969029167 & 57.10184585 \\
\hline $\mathrm{C} 6554$ & 23.040 & 4 & 5.76 & 7.0272 & 8 & 2.650886644 & 21.20709315 \\
\hline C5855 & 28.800 & 14.5 & 1.986206897 & 2.423172 & 29 & 1.556654237 & 45.14297288 \\
\hline A & 168 & 42.32 & 3.969754253 & 4.8431 & 84.64 & 2.200704476 & 186.2676268 \\
\hline B & 168 & 17.5 & 9.6 & 11.712 & 35 & 3.422279942 & 119.779798 \\
\hline
\end{tabular}

\section{Discussion}

The overlay of geological structures on the geology of the area indicates that in basement areas especially of metamorphic rocks, affected by faults and fractures groundwater accumulation are observed by the spatial location of boreholes. The faulting in the area is generally in the north-south direction which on plotting boreholes on the fault-zone map shows that the occurrence of underground water along the study area could have the same trend (Figure 5). In the western area covered by Holocene Colluvial, the geologic structures indicates that the anticline and the syncline axes are overturned resulting in the anticline becoming syncline and vice versa (Figure 6). In this area therefore the layering presently does not honor the law of superposition but rather, in the area occurs folding which resulted in thrust faulting thus overturning the lithologic formations in the area.

The central part of the area presents an undulating and plain topography. The superimposed Digital Elevation Model (DEM) information shows regions having maximum topographic high is in line with high intensity of lineaments and zones having medium to gentle gradient presenting zones with low intensity of lineaments (Figure 8 and Figure 9). The regions of topographic highs matches well with areas with high intensity of lineaments which turn to conform to areas with intense faulting (Figure 8 and Figure 9).

The comparison between results of altitude by using DEM, lineament density and drainage density have been presented (Figure 8 and Figure 9). It is evident that the areas of high altitude presents the areas of high drainage density and 


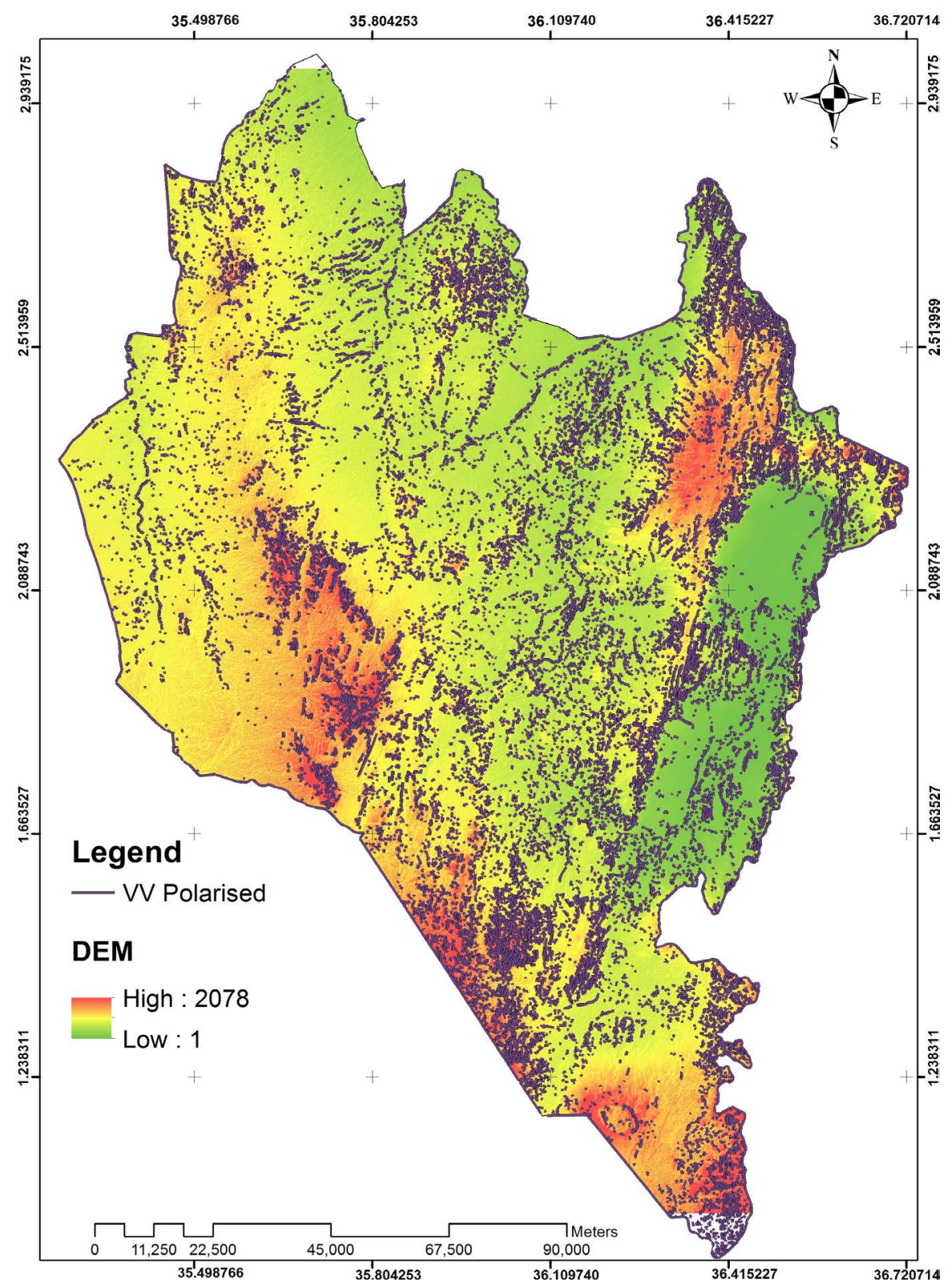

Figure 8. Showing lineament density map.

consequently the area having high density of lineaments. Lineaments indicate areas where there is concentrated faulting and this is supported by differential erosion on the ground and the degree of drainage density associated with the same (Harris et al., 2001).

The analysis of lineaments, DEM and drainage when superimposed with borehole data indicates that there is more groundwater potential associated with regions of high lineament-drainage density (Figure 4). Although boreholes seem to be spread across the study area, most of the concentration of yielding boreholes are in the high density lineament areas of high correlation with fault lines (Figure 5) which are associated with Holocene Colluvial formations mostly of arkose, greywacke and sandstone. 


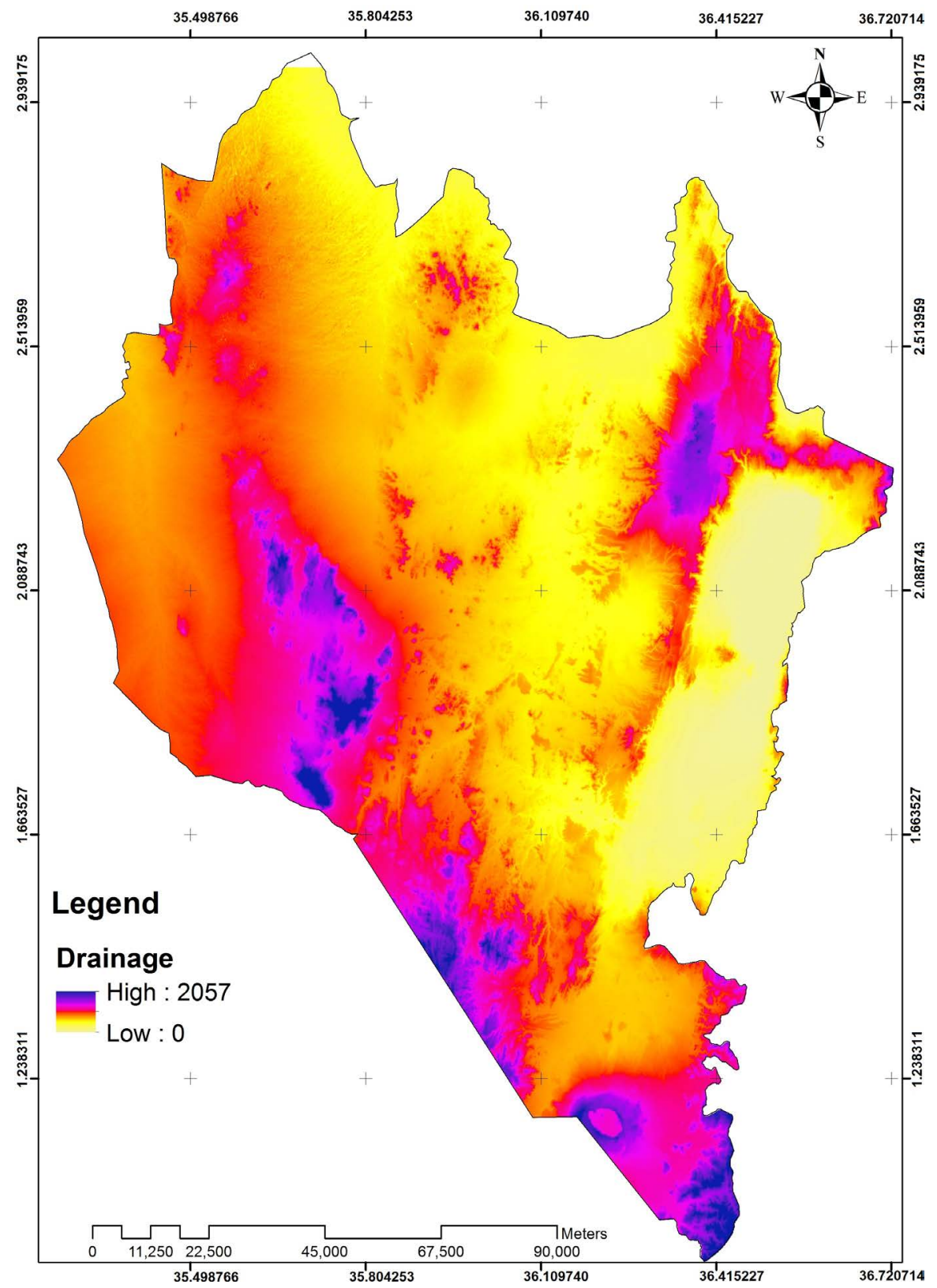

Figure 9. Showing elevation and drainage density as a proxy to groundwater potential.

The borehole data analysis has been done covering specific capacities, transmissivities and the possible radius of influence during the pumping of the boreholes. The boreholes situated in areas of low lineament density includes C5615, C5616, C5871, and C6554 with specific capacities $0.52 \mathrm{~m}^{2} /$ day, $1.26 \mathrm{~m}^{2} /$ day, 9.29 $\mathrm{m}^{2} /$ day, and $5.76 \mathrm{~m}^{2} /$ day, respectively. A further analysis of the data shows that the geology on which the boreholes are drilled determines the extend of specific capacities, boreholes (C5871 and C6554) in the igneous rocks (tuffs and basalts ) presents high specific capacities as compared to those drilled (C5615, C5616) in sedimentary rocks (sandstone, greywacke, arkoses; eolian unconsolidated rock). Similarly, boreholes drilled in high lineament density areas were analyzed and 
these include C5855 in the igneous (basalt) rock and C3789 in the sedimentary (eolian unconsolidated rock) of specific capacities $1.97 \mathrm{~m}^{2} /$ day and $6.08 \mathrm{~m}^{2} /$ day, respectively.

The areas of low lineament represents areas minimally or not affected by faulting and fracturing. It is evident that boreholes (C5871 and C6554) drilled in in these areas in volcanic rocks (like tuffs and basalts) have high specific capacities as compared to boreholes (C5615, C5616) drilled in sedimentary formations (of Sandstone, greywacke, arkoses; and eolian unconsolidated rock). This could be supported by the fact that sedimentary rocks have high degree of clays and other cementing materials which reduces the pores and subsequent porosity of the rocks thus reducing the specific capacities to a high degree. Equally volcanic rocks present good porosities and permeability due to the fact that during the cooling processes, as indeed noted by Saar \& Manga (1999), that relationship between permeability and porosity in basalts can be related to the crystal and vesicle microstructure.

Correlation of boreholes drilled in areas affected by high density lineaments indicates high level of faulting and fracturing in the area. Though there is variation when considering the same rocks and the similar specific capacities. For example the comparison of effect of the same sedimentary rocks (eolian unconsolidated rock, Figure 2), of borehole C5616 with specific capacity of 1.26 $\mathrm{m}^{2}$ /day (Table 3) drilled in low lineament density area (Figure 4), compared to C3789 of specific capacity of $6.08 \mathrm{~m}^{2} /$ day (Table 2) drilled in high lineament density area (Figure 4). There is an evidence of increase in specific capacities which means that fracturing and faulting, especially of eolian unconsolidated material is associated with increase in porosity and subsequent permeability resulting into improved specific capacities. Equally, comparison of boreholes C6554 and C5855 both drilled in basalt geologic formation with borehole C6554 having specific capacity of $5.76 \mathrm{~m}^{2} /$ day occurs in low lineament and borehole C5855 with $1.99 \mathrm{~m}^{2} /$ day in high lineament density area. The argument to support this change is that basalts weather, faster in faulted and fractured areas into clays thus resulting into reduction of pore spaces. This results into reduced porosity and permeability leading to reduction of specific capacity of the rock.

In regard to the radius of influence per specific boreholes drilled in the same rocks and in consideration of the effect of weathering, faulting and fracturing degrees. Boreholes C6554 drilled in least faulted basalt rock and C5855 drilled in highly faulted rock (Figure 5) presents 21.2 metres and 45.1 metres radii of influence, respectively (Table 3). Similarly, boreholes C5616 drilled in least faulted eolian unconsolidated sedimentary material and C3789 drilled in highly faulted eolian unconsolidated sedimentary material (Figure 5), presents radii of influence of 39.7 metres and 98.0 metres, (Table 3). Considering the two cases of borehole comparison, it is argued that the factor of weathering from faulted and fractured areas causes increase in radius of influence (Figure 5, Table 3 ).

The analysis of remote sensing data, coupled with ground truthing reflection from borehole data presents good association. The area appears to be influenced 
by large regional features which some type of geomorphic evidence agrees with the remote sensing imagery. The near infrared band represent the weathering valleys (high lineament density) which are evident because of the presence of greenness of grass, whose health status is supported by soil moisture gotten through capillary action due to the shallow groundwater table. Further observed are the dark and medium grey tones which represents open forest where the thriving vegetation are only trees with taproot and can only reach groundwater depths yonder the zones of capillary action. The lineament influence on hydrology is evident both on the ground and in comparison between lineament maps and borehole data of the area. Lineaments found in the area correlate well with fault zones, fractures, and lithological contrasts as supported by geological map and structural map, respectively (Figure 2 and Figure 5) Depending on the geology, weathering, faulting and fracturing, there could be a possible increase or a reduction in specific capacities in sedimentary rocks or basaltic rocks.

\section{Conclusion}

Lineaments can be extracted from remote sensing data and subsequently used to indicate areas of weaknesses in rock formations. These areas of weakness on the ground are associated with in geological formations and structural terranes. Thus the regions of high lineament density represents area where there is high potential for groundwater especially in sedimentary rocks in relation to other areas with low lineament density or no lineament. This is made clearer with boreholes overlaid on the lineament map, where productive boreholes are concentrated in lineament high density areas.

There is a relationship between the degree of faulting in a particular lithology and the specific capacities of boreholes drilled. Depending on the geological formation, weathering caused by faulting may increase or reduce specific capacities of productive boreholes. Similar reasons are noted for changes of radius of influence experienced during pumping of the productive boreholes. Irrespective of the kind of geological formation, the degree of weathering along fault zones generally increases the radius of influence of a borehole during pumping.

\section{Acknowledgements}

The Water Resources Authority, Kenya, was so instrumental in provision of data and towards the institution is undoubted gratefulness. Similarly acknowledgement goes to the Ministry of Petroleum and Mining, Kenya who provided with geological maps. Finally gratitude to the technicians, Chris and Fred who were instrumental in fieldwork data collection.

\section{Conflicts of Interest}

The authors declare no conflicts of interest regarding the publication of this paper. 


\section{References}

Anbazhagan, G., \& Manivel, M. (2010). Targeting Groundwater Potential Zones in Hard Rock Terrain Using Remote Sensing and GIS. Second Proof 11-02-2010, Sample Chapter, Tiruchirappalli: Department of Geology, Bharathidasan University. https://www.ikbooks.com/home/samplechapter?filename=271_Sample-Chapter.pdf

Champion, A. M. (1935a). Teleki's Volcano and the Lava Fields at the Southern End of Lake Rudolf. The Geographical Journal, 85, 323-341. https://doi.org/10.2307/1785591

Dodson, R. G. (1963). Geology of the Area South of Lodwar. Rep. 87, Geol. Surv. Kenya, Nairobi: Ministry of Petroleum and Mining Archives.

Fairburn, W. A., \& Matheson, F. J. (1970). Geology of the Loiya-Lorugumu Area. Rep. 85, Geol. Surv. Kenya, Nairobi: Ministry of Petroleum and Mining Archives.

Government of Kenya (2013). Turkana County Integrated Development Plan 2013-2017. https://turkana.go.ke/wp-content/uploads/2016/10/Turkana-CIDP-Final-1.pdf

Gwynne, M. D. (1969). The South Turkana Expedition Scientific Papers I. Preliminary Report on the 1968 Season. The Geographical Journal, 135, 331-342. https://doi.org/10.2307/1797322

Harris, J. R., Eddy, B., Rencz, A., de Kemp, E., Budkewitsch, P., \& Peshko, M. (2001). Remote Sensing as a Geological Mapping Tool in the Arctic: Preliminary Results from Baffin Island, Nunavut (13 p.). Geological Survey of Canada, Current Research 2001-E12. https://doi.org/10.4095/212696

Jawad, T. A., \& Yahya, Y. A. (2013). Application of GIS and Remote Sensing to Groundwater Exploration in Al-Wala Basin in Jordan. Journal of Water Resource and Protection, 5, 962-971. http://www.scirp.org/journal/jwarp https://doi.org/10.4236/jwarp.2013.510099

Kamal, K., \& Hamid, R. N. (2011). Groundwater Exploration Using Remote Sensing and Geographic Information Systems in a Semi-Arid Area (Southwest of Urmieh, Northwest of Iran). Arabian Journal of Geosciences, 6, 1229-1240.

https://doi.org/10.1007/s12517-011-0414-4

Klimentov, P. P., \& Pykhachev, G. B. (1961). Groundwater Dynamics.

Logan, J. (1964). Estimating Transmissibility from Routine Production Tests of Water Wells. Ground Water, 2, 35-37. https://doi.org/10.1111/j.1745-6584.1964.tb01744.x

Lohman, S. W. et al. (1972). Definitions of Selected Ground-Water Terms-Revisions and Conceptual Refinements (21 p.). U.S. Geological Survey Water-Supply Paper 1988.

Mason, P., \& Gibson, A. B. (1957). Geology of the Kalossia-Tiati Area. Rep. 41, Geol. Surv. Kenya, Nairobi: Ministry of Petroleum and Mining Archives.

McCall, G. J. H. (1964). Geology of the Sekerr Area. Rep. 65, Geol. Surv. Kenya, Nairobi: Ministry of Petroleum and Mining Archives.

Mogaji, K. A., Aboyeji, O. S., \& Omosuyi, G. O. (2011). Mapping of Lineaments for Groundwater Targeting in the Basement Complex Region of Ondo State, Nigeria, Using Remote Sensing and Geographic Information System (GIS) Techniques. International Journal of Water Resources and Environmental Engineering, 3, 150-160. http://www.Academicjournals.Org/Ijwree

Mortimore, M. (2009). Dryland Opportunities: A New Paradigm for People, Ecosystems and Development.

Obimba, O. H., Alaga, A. T., \& Alwadood, J. A. (2017). Remote Sensing and GIS Techniques for Ground Water Exploration in Ilesha Area, Osun State, Nigeria. Journal of Geography, Environment and Earth Science International, 10, 1-10. https://doi.org/10.9734/JGEESI/2017/22463 
Per Sander, Chesley, M. M., \& Minor, B. T. (1996). Groundwater Assessment Using Remote Sensing and GIS in a Rural Groundwater Project in Ghana: Lessons Learnt. $\mathrm{Hy}^{-}$ drogeology Journal, 4, 40-49. https://doi.org/10.1007/s100400050086 https://link.springer.com/Article/10.1007/S100400050086

Saar, M. O., \& Manga, M. (1999). Permeability-Porosity Relationship in Vesicular Basalts. Geophysical Research Letters, 26, 111-114. https://doi.org/10.1029/1998GL900256

Saint-Jean, R., \& Singhroy, V. (2000). Hydrogeological Mapping in the Semi-Arid Environment of Eastern Jordan Using Airborne Multipolarized Radar Images. In First Joint World Congress on Groundwater. https://doi.org/10.4095/219743 https://www.researchgate.net/publication/277244840

Sultan, R. (1970). The South Turkana Expedition: Scientific Papers III. A Geological Reconnaissance of South Turkana. The Geographical Journal, 136, 61-73.

https://doi.org/10.2307/1795682 http://www.jstor.org/stable/1795682

Turkana County Government Report (2015). Natural Resource Mapping and Context Analysis.

https://turkana.go.ke/wp-content/uploads/2016/10/Final-Report-Natural-Resource-Ma pping-Context-Analysis-10th-June-2015-1.pdf

Wada, Y., Flörke, M., Hanasaki, N., Eisner, S., Fischer, G., Tramberend, S., Wiberg, D. et al. (2016). Modelling Global Water Use for the 21st Century: The Water Futures and Solutions (Wfas) Initiative and Its Approaches. Geoscientific Model Development, 9, 175-222. https://doi.org/10.5194/gmd-9-175-2016

World Economic Forum (2017). The Global Water Initiative. http://www3.weforum.org/docs/Environment_Team/00042829_Water_initiative.pdf 